\title{
The Infrastructure Development in the Republic of Guinea
}

\author{
By Xue Mei Lan* \\ Ooi Bee Chen ${ }^{+}$ \\ Kim Seng Lim ${ }^{t}$
}

Empirical researchers indicate that the contribution of infrastructure to economic development is significant, especially in the area of long-run economic growth. Taking in consideration the importance of infrastructure to economic strength, infrastructure related topics have become topics of interest for both academicians and policy makers. Nevertheless, documented research on infrastructure development in West Africa - Guinea is rare. This paper explores the current infrastructure development in West Africa - Guinea. The data of the related infrastructure construction was investigated and collected in the statistic department of the republic of Guinea. The Cobb-Douglas production function is used to test the theoretical framework proposed. The findings show that infrastructure has a positive spillover externality to economic long-run growth and more specifically, the electricity consumption has a significant impact on economic grow in the Republic of Guinea. The author suggests that the Republic of Guinea has to invest wisely in infrastructure.

Keywords: Economic growth, Infrastructure development, West Africa.

\section{Introduction}

There are numerous definitions regarding what infrastructure is (Foster and Briceño-Garmendia 2010). According to the "World Development Report - 1994: Provide Infrastructure for Development", infrastructure can be defined as the permanent engineering building, equipment, or facilities. Although infrastructure is not very clearly defined, all definitions have two characteristics: technical features (such as economies of scale) and economic features (such as the spread of the user to the user) (World Bank 1995).

Infrastructure has an extremely important role in economic growth (Sullivan and Sheffrin 2003). Infrastructure provides commodities and services essentials to enable, sustain, or enhance societal living conditions (Fulmer 2009). According to researchers, the lack of infrastructure in many developing countries represents one of the most significant limitations to the economic growth and achievement of the Millennium Development Goals (Christian 2011). Infrastructure investments and maintains can be very expensive, particularly, in Africa, and infrastructure has been argued that it has contributed to more than half of Africa's improved growth performances between 1990 and 2005, and an increased investment is necessary to maintain growth and tackle poverty (Christian 2011).

\footnotetext{
* COMEX Resources (M) SDN. BHD. Malaysia.

${ }^{\dagger}$ Faculty Accountancy Management, Malaysia.

$₫$ CEO, Development Bank of Guinea, Republic of Guinea.
} 
Because of the importance of infrastructure to economic strength, infrastructure related topics have become topics of interest for both academicians and policy makers. Numerous studies have examined the contribution of infrastructure and the spillover externalities of infrastructure development in Africa (Foster and Briceño-Garmendia 2010). Nevertheless, documented research on infrastructure development and the spillover externalities of infrastructure development in West Africa, particularly in the Republic of Guinea, is rare. This article focuses on a narrow infrastructure in the Republic of Guinea, as defined by the World Bank's "economic infrastructure".

There are two main objectives for this study: firstly, to explore the current infrastructure development in the Republic of Guinea; secondly, to examine the relationship between the infrastructure and economic growth and the infrastructure differences of the contribution on economic growth.

The organization of this paper is as follows. The next sections review related literature and present the theoretical framework. Subsequently, the paper describes the research method and presents the results. Finally, the paper ends with a brief conclusion.

\section{Literature Review}

\section{Infrastructure and Development Economics}

In the late 1940s to 80 s, development economists faced the reality of a large population of developing countries, the surplus agricultural labor force, low income and capital investment with limited capacity size. In order to cope with these problems, infrastructure and productive investment were two organic composition parts to promote economic growth.

Rosenstein-Rodan (1943) proposed that the underdevelopment countries require large amounts of investments in infrastructure to embark on the path of economic development from their present state of backwardness, and a "bit by bit" investment programme will not impact the process of growth as much as is required for developing countries. Therefore, heavy initial investment necessarily needs to be made in social overhead capital. Compared with the direct production sector, the infrastructure construction cycle is long, the construction fund is difficult to recover in the short term, and thus it must be on time in preference to other generative investments directly. The indirect social capital includes electric power, transportation, communications, and all of the basic industries. The most important product is created for investment opportunities in other industries that "constitute the framework of that infrastructure as a share of the national economy costs". Therefore, these industries must be prior to those who are able to generate revenue faster with generative investment directly. Infrastructure must be developed through government intervention and keeping implementation plans. Only once, on a large scale, a comprehensive infrastructure investment will generate economies of scale, so that the whole community will have "external economy" benefits (Rosenstein-Rodan 1943). 
Nurkse (1953) proposed the "vicious circle of poverty" theory that says that developing countries incomes are too low, resulting in a low level of savings on the supply side and that the demand side of market capacity is too small, not enough to lure investment, which results in a vicious cycle of poverty. To break this barrier, there must be heavy investment, simultaneously, in various sectors of the national economy, rapid economic growth reaches a certain height, the per capita income is above a certain limit, which can completely out of the low-income cause a vicious cycle of poverty, and achieve rapid economic development. Nurkse's particular emphasis is on the market capacity that narrows limits on economic growth, and greatly expands the market capacity for the decisive role of rapid economic growth, at the same time that only a comprehensive investment in various economic sectors of industry, agriculture, consumer goods, capital goods production is needed in order to form the majority of the market and is sufficient to produce enough to lure investment and create conditions for further expansion of the scale of investment and further economic growth (Nurkse 1953).

Hirchman (1958) put forward the famous "unbalanced growth theory" in the "Economic Development Strategy". The key point of this theory is the subsequent development of the infrastructure and its role in ensuring economic growth. He thought that because of the limitation of the investment resources, capital investment should be concentrated to directly productive activities, and the investments in infrastructure should temporarily be postponed as soon as possible to obtain the investment income and to increase the output and income. To be generated directly in the development of production sectors up and produce a greater income, then recycle part of the income to invest in the infrastructure sector, driven by its growth (Hirschman 1958). Hirchman was entirely opposite in social indirect capital development and direct production activities on the timing of the selection opinion with Rosenstein-Rodan (1943). Hirchman (1958) believes that developing infrastructure to implement would be a state intervention and economic plan, but would have a stronger emphasis on the role of the market mechanism, stressing that the "lead investment" role should develop priority and the direct production sector "bottleneck" pressure should stimulate the development of infrastructure.

\section{The Empirical Research of Infrastructure}

In addition to the development of the economics literature the studies of infrastructure in mainstream economics are mainly evident in recent decades. Although Arrow and Kurz were first included in the public capital stock in the aggregate production function, due to the fact that the equilibrium of the model was uncertain, that period of time it did not cause much attention (Arrow and Kurz 1970). Arrow and Kurz firstly introduced the public capital stock aggregate production function, the establishment of the functional form is:

$$
Y(t)=F\left[K(t), G(t), L(t) e^{x t}\right]
$$


where,

$\mathbf{K}(\boldsymbol{t})$ represents the private capital stock,

$\mathbf{G}(\boldsymbol{t})$ represents the common capital stock of pure public goods nature,

$\mathbf{L}(\boldsymbol{t})$ represents the labor capital, $x$ is the technological progress rate of increasing labor productivity, and given by exogenous.

Until the late 1980s, early 1990s, a concept of sustainable development gradually formed, driven by the World Bank, economists began large-scale infrastructure and economic growth was studied.

The World Bank made a wide range of empirical research, on the role of infrastructure in economic development. The report noted that the infrastructure capital stock has a substantial effect on economic growth, but also in comparison with other forms of capital stock, this role is growing. This report lists the empirical research data of a number of authors which focus on the elasticity that percent change of infrastructure capital stock to percent change of output and the effect that infrastructure capital stock to reduce production costs, and most of the authors got the conclusion of obvious positive effect (World Bank 1995).

Aschauer's (1989a, 1989b, 1989c) empirical research regarding the relationship between infrastructure and economic growth has been a groundbreaking contribution. He used the US time-series and cross-sectional data 1945-1985 years, and studied the overall productivity, government spending (not including defense spending) and the relationship between the formation of the capital. His research suggests that the marginal yield of infrastructure has twice as many large private investments. Infrastructure by increasing the productivity of the private sector and public expenditure increases the rate of return on private capital investments to stimulate and achieve investment growth (Aschauer 1989a, Aschauer1989b, Aschauer 1989c).

Research used the more flexible beyond the logarithmic production function to replace the original Cobb-Douglas production function. Merriman used, beyond the logarithmic production function, the Japan nine regions data from 1954 to 1963 and found that the public capital output elasticity is 0.43 0.43 (Merriman 1990). Ford and Poret used data from 1960 to 1989 of 11 OECD countries and found that the output elasticity of public capital is 0.39 to 0.54 (Ford and Poret 1991).

Douggal et al. (1999) treated infrastructure as part of the technical growth restriction into the model, making infrastructure and technological progress to present an interactive relationship, constructed an "S" shape of production function, and estimated results to show that the infrastructure plays an important role in economic growth (Duggal et al. 1999).

Other researchers used the first-order difference method to estimate the results that were often much lower than Aschauer's result and even found that social capital has a negative effect. Tatom (1991) pointed out that Aschauer (1989a) ignores the characteristics of the time series of data in his economic analysis, so the conclusion is unusually high. Tatom (1991) used first order 
difference and regression again, and the results showed that infrastructure would be no such a high elasticity, only 0.14 (Tatom 1991).

Some research scholars believe that constituting different types of infrastructure in varying degrees has impact on economic growth. Canning (1999) and Fay and Canning (1993) proved that core infrastructures, such as highways have a larger contribution than that of non-core infrastructures for economic growth. Through the 57 countries of the 1960 and 1990 data, that used the variable logarithmic form, the estimated output elasticity of transportation was significantly higher than that of electricity and telecommunications. The same infrastructure for high-income and low-income countries elastic difference is very big. Such as transportation which was 0.174 for high income elasticity countries and 0.050 for low-income countries (Canning 1999, Fay and Canning 1993).

At the same time of the empirical research the theoretical work also had substantive progress. Barro (1990) included public investment flows into the aggregate production function (Barro 1990). The establishment of a production function form is:

$$
Y(t)=f[K(t), I G(t)]=K 1-a(t) I a G(t)
$$

where,

$\mathbf{I}_{\mathbf{G}}(\mathbf{t})$ represents public investment flows, a represents the output elasticity of public investment.

With Arrow and Kurz (1970) the model is different. Barro assumed that public investment flows directly access to the aggregate production function, rather than the public capital stock. In Barro's (1990) view, the output is not only associated with the physical capital level of the private sector, and the government through public spending on infrastructure. The research, development and education spending also have positive effects on the output. So he included the government public expenditure of tax support into the endogenous economic growth model. Barro (1990) effectively established the production link between government expenditure and economic growth: under the Cobb-Douglas production function, the government activities can make up for the inadequacy of the decentralized savings and the pushing steady growth.

\section{Infrastructure Development in Republic of Guinea}

According to the data at the statistical department of the Republic of Guinea, the current situation of the infrastructure can be present with highway, railway, air transport, water transport, communications, internet and electricity as followed:

- Highway: All kinds of highway roads with a total mileage of $37,774 \mathrm{~km}$, including $8,970 \mathrm{~km}$ of national roads $(2,218 \mathrm{~km}$ asphalt), regional highway 
$6,770 \mathrm{~km}, 21,034$ ten thousand $\mathrm{km}$ of rural roads, and 1,000 km of urban roads. The roads mostly lack maintenance and are seriously damaged.

- Railway: Currently guinea has three railways operating with about 400 $\mathrm{km}$, all bauxite special railway, including: de Baylor - Conakry port (about $130 \mathrm{~km})$, Boke - Kamsar port (135 km), and Fria - Conakry port $(145 \mathrm{~km})$. France built the original railway Niger, which has already been abandoned, its railroad tracks have been stolen and it has a badly damaged roadbed.

- Air Transport: A total of 16 airports nationwide. Where 11 civil airports, mining companies owned 5 airports. Gbessia International Airport of Conakry is the only international airport in guinea. 7,008 sorties in 2008, up to $14.8 \%$ from a year earlier, and carrying 292,000 passengers, up to $13.2 \%$ from a year earlier. In the mainland airports except the Labe airport and the "Zerekore airport" which are for civil transport, other airports have been abandoned or are used for Guinea's military possesses.

- Water Transport: Mainly Conakry port Main Channel has a length of 5,000 meters, is 150 meters wide, and its average depth is 9.5 meters, the annual throughput is 5 million tons. It has container terminals, oil terminals, an aluminum dock (Fria Alumina Company dedicated), a commercial dock, and a fishing pier. The Container Terminal is 270 meters long, with an area of 80,000 square meters, it has a depth of 10 meters and it can accommodate 250,000 DWT container ships. The annual container handling capacity is 50,000 . The Oil terminal is 190 meters long, it has a 10 meter water depth and can accommodate 250,000 DWT container ship, and is capable of accommodating 45,000 tons after dredging oil tankers. Kamsar Port is the bauxite special port, mainly from the Guinea Bauxite Company (CBG) to manage and use, Annual handling a capacity of about 12 million tons of bauxite.

- Communications: The telecom market development lags behind and the fixed telephone and mobile phone penetration rate is very low. Currently only the guinea fixed-line telecom companies have an operating license, there are only 26,000 fixed telephone users across the country, and only parts of the capital and several major cities in the fixed telephone can be used normally. Guinea has about 1.8 million mobile phone users, a total of five operators to operate mobile services, namely: Guinea telecom companies, account for $25 \%$ of the market share, AREEBA company (MTN Group), accounts for $54.7 \%$ of the market share, INTERCEL company approximately for 100,000 existing mobile users, Senegal telecommunications company in Guinea (brand Orange) for about $15 \%$ of the market share, with the development of greater potential; CELCOM company is the US capital companies.

- Internet: Mainly provided by the local ISP, the charges are very high, urgent need to improve network quality. Guinea's post office has stateowned enterprises for its autonomous management. The national post office and the total number of post offices are 205, mainly through the 
French postal service, and postal services around the world. Mail, including ordinary mail, registered mail, and national courier.

- Electricity: Guinea's hydropower resources are rich. It has abundant rainfall, an undulating terrain and is the birthplace of the Niger, Senegal and Gambia River, the West African three rivers, and is known as the "water tower of West Africa". Its hydropower reserves up to 63 billion degrees. The Garafiri hydropower station is the largest hydropower station in guinea, with an installed capacity of 75,000 KW, and a total investment of $\$ 238$ million in 1998 formally connected to the grid. Another Conakry Tombol thermal power station (capacity 22,000 KW), Aggreko thermal station (3,400 KW), and so on. Guinea's electricity supply is very tight, especially in the dry season when the hydroelectric power is not sufficient. In addition to the capital of the central area of the country, the rest need to be self-generators.

\section{Theoretical Framework and Variables}

Before studding the infrastructure differences of contribution on economic growth, we must first learn the relationship between infrastructure and economic growth.

\section{Infrastructure and Economic Growth}

There are many empirical studies on the relationship between infrastructure and economic growth, mainly in four ways: the production function, cost function and profit function, vector auto regression and cross-sectional data regression. Due to the production function method a clear and simple model is defined, many economists such as Aschauer (1989a), Canning (1999) used it to study the effect of infrastructure on economic growth. This study chose the production function method, and used the Cobb-Douglas production function to examine the relationship between infrastructure and economic growth.

The Cobb-Douglas production function was developed and tested against statistical evidence by Charles Cobb and Paul Douglas during 1927-1947 (Cobb and Douglas 1928). In this study, we selected the main input factors in the equation of economic growth as explanatory variables (Table 1). We believe that using the Cobb-Douglas function to establish the growth model for Guinea and to estimate the contribution of the infrastructure to economic growth is the right choice. The reasons are the following: first of all, the parameters of the CobbDouglas production function model have clear economic sense, it is one of the most commonly used production functions, it can be well described, including the infrastructure and each factor contributes to the economic growth. Secondly, the statistical data is relatively scarce in Guinea, we can only make the best use of the limited data to get more useful information. The Cobb-Douglas production function is able to meet these requirements. 
Earlier researches typically put the infrastructure capital stock as an independent public capital outside the private capital to study and investigate its output elasticity of the total output (Aschauer (1989c, Munnell 1990).

According to the general infrastructure research model, we assume that the gross output production function is:

$$
Y_{t}=A_{t} K_{t}^{c 1} L_{t}^{c 2} G_{t}^{c 3}
$$

Table 1. Variables Description I

\begin{tabular}{|c|c|}
\hline Variables & Representing \\
\hline Y & GDP \\
\hline A & Technological Progress \\
\hline K & Physical Capital Stock \\
\hline L & Labor Force \\
\hline G & Infrastructure Capital Stock \\
\hline
\end{tabular}

Source: Authors' estimations.

$\mathbf{Y}_{\mathbf{t}}$ is in constant prices (2003) to calculate the total output GDP (billion USD) in year $t$,

$\mathbf{A}_{\mathbf{t}}=\mathbf{A}_{\mathbf{0}} \mathbf{e}^{\lambda \mathbf{t}}$ represents that technical progress factor change with time, and assumes that it is hicks neutral,

$\mathbf{K}_{\mathbf{t}} \quad$ is in constant prices (2003) to calculate the physical capital stock (billion USD) in year $t$. The data is from the statistical department of the Republic of Guinea,

$\mathbf{L}_{\mathbf{t}} \quad$ represents the total number of labor force (million) in year $t$. The data is from the statistical department of the Republic of Guinea.

Changed the production function (3) into a logarithmic linear model:

$$
\begin{array}{r}
\left(a_{t}=\operatorname{In} A_{t}=a_{0}+{ }^{\lambda \mathrm{t}}\right) \\
y_{t}=a+{ }^{c 1} k_{t}+{ }^{c 2} l_{t}+{ }^{c 3} g_{t}
\end{array}
$$

In the formula, the lowercase variables represent the logarithmic form of uppercase variables.

Most studies accept the assumption of the constant return of the scale, so we accept the assumption of the constant return to the scale, the production function is:

$$
Y_{t^{-}} l_{t}=a+{ }^{c 1}\left(k_{t^{-}} l_{t}\right)+{ }^{c 2}\left(g_{t}-l_{t}\right)
$$

After the ADF test, $y_{t^{-}} l_{t}, k_{t^{-}} l_{t}$ and $g_{t}-l_{t}$ ), all are single integer sequences. In order to make the sequence become a steady sequence, conducting differentia conversion to the formal (5)

$$
\Delta\left(y_{t^{-}} l_{t}\right)=c_{0}+c_{1}^{*} \Delta\left(k_{t^{-}} l_{t}\right)+c_{2}^{*} \Delta\left(g_{t}-l_{t}\right)
$$


Finally add an error term, it is the complete regression equation:

$$
\Delta\left(y_{t^{-}} l_{t}\right)=c_{0}+c_{1} * \Delta\left(k_{t^{-}} l_{t}\right)+c_{2}^{*} \Delta\left(g_{t}-l_{t}\right)+\varepsilon
$$

\section{Infrastructure Differences of Contribution on Economic Growth}

In order to investigate the effect of infrastructure, earlier researches typically put infrastructure capital stock as an independent public capital outside the private capital to study and investigate its output elasticity of the total output. Such as Aschauer (1989c) and Munnell (1990) did. Later, economists gradually began to decompose the effect of the public capital and respectively study the output elasticity of various kinds of infrastructures. Such as Garcia-Mila et al. (1996) examined highways, water supply and drainage, and other impacts on economic growth, and Canning (1999) studied the output elasticity of paved roads, power generation capacity, and telephone lines. For infrastructure variable selection, Garcia-Mila et al. (1996) selected the gross index. Canning(1999) supposed constant returns to the scale of production function, converted gross index into per capita index, including phone lines, power generation capacity, and kilometers of roads, all in per worker terms. Démurger (2001) used road density in the study of transportation infrastructure.

To test the effect of the infrastructure for economic growth we will combine it with previous research experience, and consider adding the infrastructure index into Cobb-Douglas production function. Since the statistical data of the infrastructure is relatively limited in the Republic of Guinea, we will combine the existing research and the definition of the World Bank, and choose the representatives of transportation, energy and communications which are highway grade (HW), electricity generation (EL) and telephone lines subscriptions (TE) as explanatory variables (Table 2).

Assume that the production function has the following form:

$$
Y_{t}=A_{t} K_{t}^{c 1} L_{t}^{c 2} H W_{t}^{c 3} E L_{t}^{c 4} T E_{t}^{c 5}
$$

Table 2. Variables Description II

\begin{tabular}{|c|c|}
\hline Variables & Representing \\
\hline Y & GDP \\
\hline A & Technological Progress \\
\hline L & Physical Capital Stock \\
\hline HW & Labor Force \\
\hline EL & $\begin{array}{c}\text { Highway grade mileage (HW) } \\
\text { Transportation variable }\end{array}$ \\
\hline TE & $\begin{array}{c}\text { Electricity generation (EL) } \\
\text { Energy variable }\end{array}$ \\
\hline
\end{tabular}

Source: Authors' estimations. 
$\mathbf{Y}_{\mathbf{t}}$ is in constant prices (2003) to calculate the total output GDP $\mathbf{A}_{\mathrm{t}}=\mathrm{e}^{\mathrm{a}+\mathrm{bt}}$ (billion USD) in year $t$,

represents technological progress, as we use the panel data,
including fixed effects a, also includes changes over time and increase the productivity effect of $b_{t}$,

$\mathbf{K}_{\mathbf{t}} \quad$ is in constant prices (2003) to calculate the physical capital stock (billion USD) in year $t$. The data is from the statistical department of the Republic of Guinea,

$\mathbf{L}_{\mathbf{t}} \quad$ represents the total number of labor force (million) in year $t$. The data is from the statistical department of the Republic of Guinea,

$\mathbf{H W}_{\mathbf{t}}$ is the variable of transportation infrastructure, represents highway grade mileage in year $t$. The data is from the statistical department of the Republic of Guinea,

$\mathbf{E L}_{\mathbf{t}}$ is the variable of energy infrastructure, represents the electricity generation (billion kilowatt-hours) in year $t$. The data is from the statistical department of the Republic of Guinea,

$\mathbf{T E}_{\mathbf{t}} \quad$ is the variable of communication infrastructure, represents the telephone lines subscriptions in year $t$. The data is from the statistical department of the Republic of Guinea.

We found that the VIF of all variables were less than 10, by using panel data regression and the variance inflation factor method (VIF) test multicollinearity, from which the selection of infrastructure variables that can be identified are based on a physical indicator. A serious collinearity problem does not exist between the physical capital stock variable and the infrastructure variables, so the regression analysis is not greatly affected.

Changed the production function (8) into a logarithmic linear model:

$$
\begin{array}{r}
\left(\operatorname{In} A_{t}=a+b_{t}\right) \\
y_{t}=a+b_{t}+{ }^{c 1} k_{t}+{ }^{c 2} l_{t}+{ }^{c 3} h w_{t}+{ }^{c 4} e l_{t}+{ }^{c 5} t e_{t}
\end{array}
$$

Lowercase variables represent the logarithmic form of the uppercase variables. Due to constant returns to the scale, to change in the form of the production function (9),

$$
y_{t}-l_{t}=a+b_{t}+{ }^{c l}\left(k_{t^{-}} l_{t}\right)+{ }^{c 2}\left(h w_{t^{-}} l_{t}\right)+{ }^{c 3}\left(e l_{t^{-}} l_{t}\right)+{ }^{c 4}\left(t e_{t^{-}} l_{t}\right)
$$

Finally, combined with the error term, that is the complete regression equation:

$$
y_{t}-l_{t}=a+b_{t}+{ }^{c l}\left(k_{t^{-}} l_{t}\right)+{ }^{c 2}\left(h w_{t^{-}} l_{t}\right)+{ }^{c 3}\left(e l_{t^{-}} l_{t}\right)+{ }^{c 4}\left(t e_{t^{-}} l_{t}\right)+u_{t}
$$




\section{Research Methods}

In this paper, combining the theoretical and empirical analysis methods has both a theoretical basis and a practical significance. Data was collected from the statistics department of the Republic of Guinea, and combined with the World Bank database of data, after sorting and analyzing the Guinea current infrastructure situation.

The empirical research to analyze the effect that infrastructure has on economic growth in the Republic of Guinea, on the basis of the existing literature research method using the Cobb-Douglas production function and the output elasticity of infrastructure capital stock that was examined, verified that the infrastructure has a significant promoting effect on economic growth.

Then, the focus was on the transportation, energy, communications infrastructure contribution of differences. Infrastructure variables were introduced into the Cobb-Douglas production function, their respective output elasticity was examined, and a significant effect outside the physical capital stock on output was understood as the externality of the infrastructure. Further, the panel data and the fixed effects model were used to test the externality of these infrastructures.

\section{Results and Findings}

The collection of data about infrastructure shows the present situation of infrastructure in the Republic of Guinea and that Guinea has underdeveloped inland transportation, particularly road transportation which is the country's main transportation system. Additionally, the fixed-line telecommunications and electricity generation infrastructure is seriously underdeveloped.

Table 3. OLS Regression Results

\begin{tabular}{|c|c|}
\hline & Coefficient \\
\hline $\mathbf{C}$ & -0.0167 \\
& $(-1.03)$ \\
\hline $\mathbf{K}$ & $0.5446 * * *$ \\
& $(2.63)$ \\
\hline $\mathbf{G}$ & $0.4012 * *$ \\
& $(2.35)$ \\
\hline
\end{tabular}

Note: $* * *$ and $* *$ respectively at $1 \%$ and 5\% significant level. It is the statistics of $(t)$ in the bracket. Source: Authors' estimations.

$$
\begin{gathered}
\text { Regression results (12): } \\
\Delta\left(y_{t^{-}} l_{t}\right)=-0.0167+0.5446 * \begin{array}{l}
\Delta\left(k_{t}-l_{t}\right)+0.4012 * \Delta\left(g_{t}-l_{t}\right) \\
(-1.03)
\end{array}
\end{gathered}
$$

As shown in Table 3, through the regression analysis, we found that in addition to the material capital, the infrastructure capital stock also played a significant boost to economic growth. The infrastructure capital stock of the output elasticity is about 0.4012 , the result is similar with Aschauer's (1989b) conclusions. 
Table 4. Regression Results

\begin{tabular}{|c|c|c|}
\hline & OLS & Fixed effects \\
\hline \multirow{2}{*}{ K } & 0.3374 & $0.5284 * * *$ \\
& $(10.33)$ & $(14.35)$ \\
\hline \multirow{2}{*}{ HW } & 0.4514 & $0.0690^{* *}$ \\
& $(9.41)$ & $(2.34)$ \\
\hline \multirow{2}{*}{ EL } & -0.2236 & $0.0517 * * *$ \\
& $(-9.76)$ & $(2.75)$ \\
\hline \multirow{2}{*}{ TE } & 0.1645 & 0.0306 \\
& $(10.13)$ & $(4.01)$ \\
\hline
\end{tabular}

Note: $* * *$ and $* *$ respectively at $1 \%$ and $5 \%$ significant level. It is the statistics of $(t)$ in the bracket. Source: Authors' estimations.

As shown in Table 4, the first column is mixed with the OLS model to carry on the regression results, the second column is the fixed effects model to carry on the regression results. We found that the Capital stock of the output elasticity is up to 0.53 , the effect of capital in promoting economic growth is very obvious. In addition to the communication infrastructure of the telephone line subscriptions (TE) is not significant. The representative indicator of transportation is highway grade (EL), and for energy is electricity generation $(\mathrm{HW})$, these are at $1 \%$ and 5\% significant level respectively, making them significant. According to Canning (1999), since we have included the infrastructure stock in the physical capital stock, if the output elasticity of the infrastructure variable is positive, it indicates that it has strong externalities and above-average productivity. Therefore, we believe that the externality of transportation and energy are very obvious, its marginal productivity is more than other physical capital. Although the communications infrastructure has effect on economic growth, but does not have strong external effects, its productivity is substantially the same with the other capital. From the findings we can see transportation has more significant effects than electricity consumption on the economic growth.

\section{Conclusions}

Overall, this study used Guinea's official data and World Bank data sorting out and analyzing, and through the macro measurement method, investigated the current infrastructure development in the Republic of Guinea. Meanwhile, the examined theory and empirical research in the domain shows that infrastructure has a significant effect on economic growth, and the infrastructure differences of contribution on economic growth in the Republic of Guinea.

The results of this study provide a theoretical basis for infrastructure construction and the economic development for the government of Guinea. According to the findings and in response to the lag of infrastructure construction, the author suggests that the Republic of Guinea has to increase the public capital investment. Furthermore, the Republic of Guinea has to invest wisely in 
infrastructure which is critically important as over investment can lead to projects that are inefficiently large with low marginal returns.

The significances of this study are twofold. Firstly, the research verified that infrastructure has a significant effect on economic growth. In order to solve the constraints that the inadequacy of the infrastructure capital stock on economy, the government of Guinea should, through direct investment and mobilization of social resources, invest on a large scale investment in transportation, energy, telecommunication construction and other infrastructures, making the related fields product or service shortages continue to improve, as well as provide an important basis of conditions for sustained economic growth.

Secondly, most of the research in the contribution of infrastructure to economic development is significant, especially in the area of long-run economic growth. Nevertheless, documented research on the infrastructure development and the spillover externalities of infrastructure development in West Africa, particularly in the Republic of Guinea, is rare. This study helps address the rare infrastructure development in the Republic of Guinea.

\section{Acknowledgments}

Firstly, I would like to acknowledge my supervisor, Ms Ooi who guided and helped me study this thesis with heart and soul. Thanks for all of the surveyed Guinea officers which have contributed and supported me to complete this survey. Special, thanks for Dr. Lim Kim Seng who is the Directeur Generale/CEO of the Banque de Developpement de Guinee SA of the Republic of Guinea for helping me contact and coordinate the survey. Thank you very much!

\section{References}

Arrow K, Kurz M (1970) Public Investment, the Rate of Return, and Optimal Fiscal Policy. Baltimore: The John Hopkins Press.

Aschauer DA (1989a) Is public expenditure productive? Journal of Monetary Economics 23: 177-200.

Aschauer DA (1989b) Public investment and productivity growth in the group of seven. Economic Perspectives 23: 17-25.

Aschauer DA (1989c) Does public capital crow out private capital? Jourmal of Monetary Economic Perspectives 13: 17-25.

Barro R (1990) Government spending in a simple model of endogenous growth. Journal of Political Economy 98: 103-125.

Canning D (1999) The contributions of infrastructure to aggregate output. World Bank Policy Research Working Paper.

Christian KMK (2011) Mapping the new infrastructure financing landscape. London: Overseas Development Institute.

Cobb CW, Douglas PH (1928) A theory of production. American Economic Review 18(Suppl.): 139-165.

Démurger S (2001) Infrastructure development and economic growth: an explanation 
for reginal disparities in China? Journal of Comparative Economics 29: 95-117.

Duggal VG, Saltzman C, Klein L (1999) Infrastructure and productivity: a nonlinear approch. Journal of Econometrics 92: 47-74.

Fay M, Canning D (1993) The Effect of Transportation Network on Economic Growth. Discussion Paper Series, Columbia University.

Ford R, Poret P (1991) Infrastructure and Private Sector Performance. OECD Economic Studies 17: 63-89.

Foster V, Briceño-Garmendia C (2010). Africa infrastructure country diagnostic. Overhauling the engine of growth: infrastructure in Africa. DC: World Bank.

Fulmer J (2009) "What in the world is infrastructure?". PEI Infranstructure Investor (July/August): 30-32.

Garcia-Mila T, McGuire TJ, Porter RH (1996) The effect of public capital in state level production functions reconsidered. Review of Economics and Statistics 1(Feb.): $177-180$.

Hirschman AO (1958) The Strategy of Economic Development. Yale University Press.

Merriman D (1990) Public capital and regional output: another look at some japanese and american data. Regional Science and Urban Economics 20: 437-458.

Munnell AH (1990) Why has productivity growth declined? productivity and public investment. New England Economic Review, Federal Reserve Bank of Boston, Jan/Feb: 3-22.

Nurkse R (1953) Problems of Capital Formation in Underdeveloped Coutries. Oxford University Press.

Rosenstein-Rodan P (1943) Problems of Industrialization in Eastern and SouthEastern Europe. Economic Journal 53: 202-211.

Sullivan A, Sheffrin SM (2003) Economics: principles in actions. Upper Saddle River, New Jersey: Pearson Prentice Hall, p. 474.

Tatom J (1991) Should government spending on capital goods be raised. Federal Reserve Bank of St. Louis Review March/April: 3-15.

World Bank (1995) World Development Report 1994. Retrieved from https://goo.gl/ccI7aV. 